Supplement of Clim. Past, 16, 1451-1467, 2020

https://doi.org/10.5194/cp-16-1451-2020-supplement

(c) Author(s) 2020. This work is distributed under

the Creative Commons Attribution 4.0 License.

(c) (1)

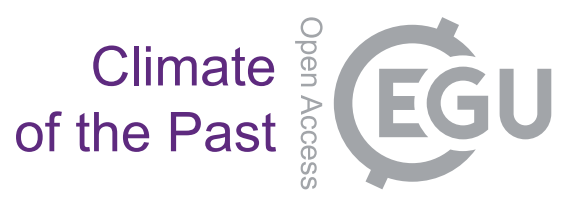

Supplement of

\title{
Sea surface temperature in the Indian sector of the Southern Ocean over the Late Glacial and Holocene
}

\section{Lisa Claire Orme et al.}

Correspondence to: Lisa Claire Orme (lisa.orme@mu.ie)

The copyright of individual parts of the supplement might differ from the CC BY 4.0 License. 


\section{Supplementary Information 1}

\section{Comparison of the COR1GC SST reconstruction with temperature and sea ice extent reconstructions}

from the EDML ice core

We here compare the timings and patterns of Southern Ocean SST from the COR1GC record with proxyseries for atmospheric temperature $\left(\delta^{18} \mathrm{O}\right)$ and regional sea ice extent (ss Na flux) during the late deglaciation and Holocene from the EDML ice core (EPICA Community Members, 2006; Fischer et al., 2007). The EDML records were selected for comparison as they represent the closest ice cores to the western Indian sector of the Southern Ocean (Figure 1), are in the area considered to be the moisture source for the EDML core (e.g. Lewis et al, 2013) and provide a high resolution proxy record for the past variability of air temperature and sea ice extent.

Each dataset were normalised and a SiZer smoothing (using the local linear kernel estimator) with a bandwidth of 400 years was applied (Chaudhuri and Marron, 1999). The changes in temperature and sea ice extent (Figure S1) show near-synchronous changes during the late deglaciation. However, it is noteworthy that despite similar timings of warming/sea ice retreat during the Younger Dryas, the chronological uncertainties in both the COR1GC and EDML records prevent further assessment of the leads and lags. Holocene patterns of variability are more divergent, although the SST and EDML temperature $\left(\delta^{18} \mathrm{O}\right)$ records show similar millennial-scale changes. We refrain from conducting correlation analysis on the series due to a relatively high level of smoothing applied and the associated low number of degrees of freedom.

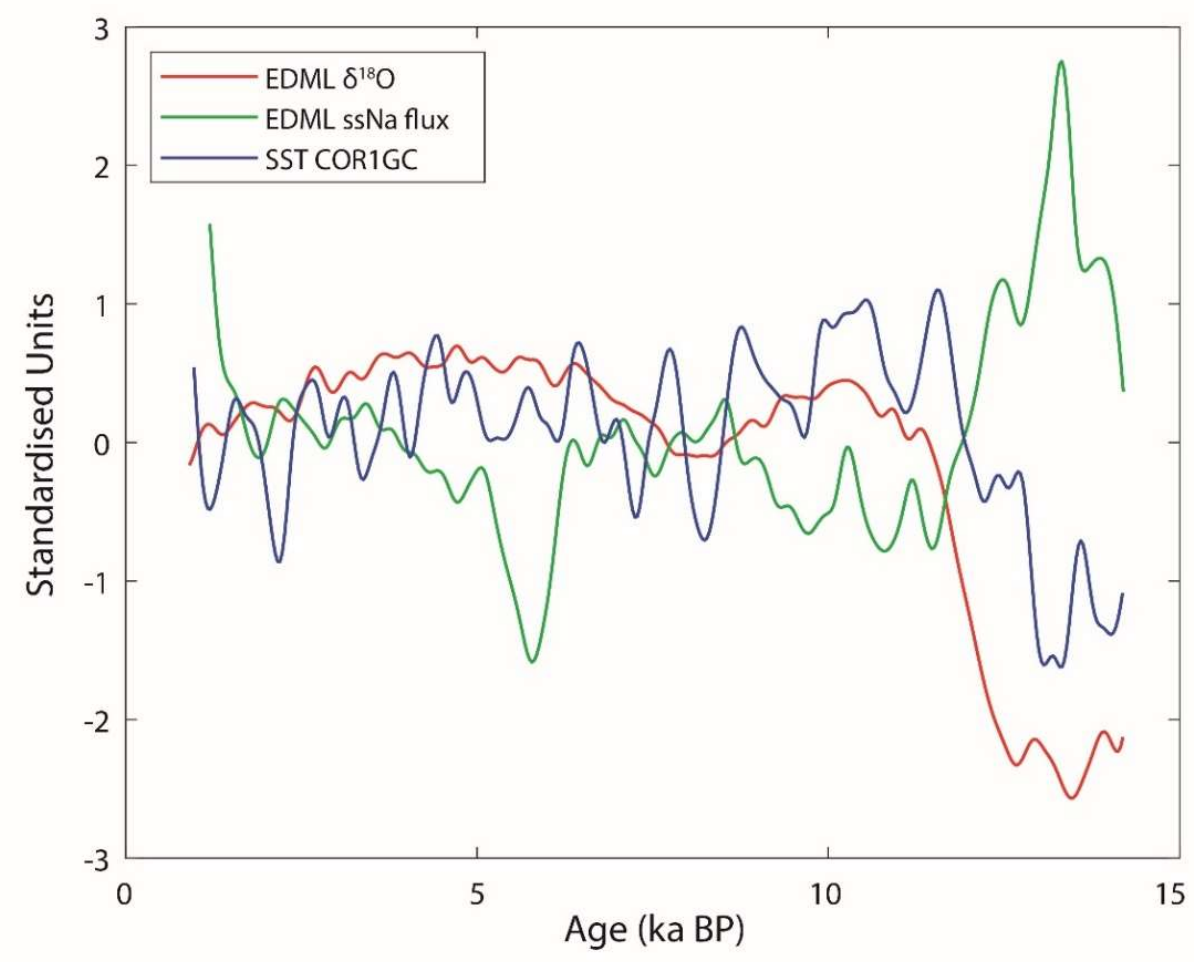

Figure S1: Comparison of the normalised and smoothed data from the COR1GC SST reconstruction and the reconstructions of $\delta^{18} \mathrm{O}$ and ssNa from the EDML ice core. 


\section{Bibliography}

Chaudhuri, P. and Marron, J. S.: SiZer for exploration of structures in curves. J. Am. Stat. Assoc., 94(447), 807-823, doi:10.2307/2669996, 1999.

EPICA Community Members: One-to-one coupling of glacial climate variability in Greenland and Antarctica. Nature, 444(7116), 195, doi:10.1038/nature0530, 2006.

Fischer, H. et al.: Reconstruction of millennial changes in dust emission, transport and regional sea ice coverage using the deep EPICA ice cores from the Atlantic and Indian Ocean sector of Antarctica. Earth Planet. Sci. Lett., 260(1-2), 340-354, doi: 10.1016/j.epsl.2007.06.014, 2007.

Lewis, S. C., A. N. LeGrande, M. Kelley, and G. A. Schmidt (2013), Modeling insights into deuterium excess as an indicator of water vapor source conditions, J. Geophys. Res. Atmos., 118, 243-262, doi:10.1029/2012JD017804 